\title{
8. Low Wages, Low Rents, and Pension Cheques: The introduction of equal wages in the Kimberley, 1968-1969
}

\author{
Fiona Skyring
}

The introduction of equal wages for Kimberley Aboriginal pastoral station workers $^{1}$ during the northern wet season of 1968-69 has been characterised as a disaster - the cause of mass evictions and unemployment in Western Australia's far north. Former stockmen such as John Watson and Eric Lawford, who recorded their accounts in the publication Raparapa, remembered the devastating impact of being kicked off the stations. The evictions were particularly destructive because the stations were on the traditional country of most of the Aboriginal people who lived and worked there. Significantly, although they remembered the period as catastrophic, none of these Kimberley Aboriginal men said they did not want proper wages (Marshall 1998). Peter Yu, former Executive Director of the Kimberley Land Council, wrote that the equal wages decision 'broke the back of the feudal relationship between station managers and Aboriginal families. Pastoralists began to force Aboriginal people from the stations which precipitated a refugee crisis of enormous proportions' (Yu 1994:19).

Historian Bill Bunbury argued that the implementation of the equal wages decision was badly planned and had ruinous consequences. It ultimately meant loss of work, skills and land for the Aboriginal people the decision was supposed to benefit (Bunbury 2002). But while no-one in these contemporary analyses has argued that Aboriginal station workers should have continued to be paid the pittance they received for their labour before 1968, there was the inference in Bunbury's account that equal wages were bad for Aboriginal workers. This idea was openly discussed in 1968, and station employers and some State Government officials argued that money in the hands of Aboriginal people was a dangerous thing. Station owners at the time cited Aboriginal people's alleged inability to manage money as one of the excuses to keep the wages

\footnotetext{
1 Throughout this chapter I use the word 'Aboriginal' and not 'Indigenous'. In the work I have done for the Aboriginal Legal Service of Western Australia Incorporated (ALSWA), the Executive Committee has always preferred that option. The members of the Executive Committee are elected from Aboriginal communities across the State, and 'Aboriginal' is the term they use when not identifying more specifically with their traditional country, such as Noongar or Bardi. When I was asked to research and write ALSWA's submissions to the Senate Legal and Constitutional Affairs Committee Inquiry into Stolen Wages in 2006, the Executive Committee asked me to adopt the word 'Aboriginal' even though the terms of reference for the inquiry referred to 'Indigenous' people and wages. See ALSWA (2006a:10). I am grateful to ALSWA for their permission to quote from the research materials I used for the submissions I prepared for the Senate Committee Inquiry.
} 
of their Aboriginal employees negligible or non-existent, even though it was Aboriginal labour that sustained the regional economy. In today's context of the Federal Government's authoritarian micro-management of Aboriginal people's abysmally low incomes - with echoes of the notion that Aboriginal people are not capable of managing their own money - the background to the introduction of equal wages for Aboriginal workers is worth revisiting. The event is also important for analyses of the northern Australian economy generally. In relation to non-Aboriginal workers, the argument that employers could not afford to pay their workers a minimum wage would be considered risible.

There are some enduring misconceptions about the history of the northern Australian economy and in particular about the impact of the introduction of equal wages for Aboriginal workers. Thalia Anthony, in her work about Aboriginal pastoral workers in the Northern Territory, referred to the introduction of equal wages there in 1966 as an event 'shrouded in myths'. Equal wages for Aboriginal station workers were 'just one factor in a range of transformations', including the increased use of helicopter mustering and a worldwide recession that changed the workforce profile of the northern cattle industry. Along with these changes was a new direction in government policy that made it increasingly difficult for station owners to argue that because they supported the elderly dependants of Aboriginal workers they could deny or reduce wages to their Aboriginal workers accordingly. This was a spurious argument anyway, since most of these so-called dependants worked in some capacity around the station (Anthony 2006).

As in the Northern Territory, in the Kimberley the introduction of equal wages was not the sole cause of social disaster. There were other economic factors that contributed to the impact of the award decision. Some of these economic factors, I argue, were specific to Western Australia and have received little attention in historical analyses of the trauma that unfolded in the far north of Western Australia in 1969. The social and economic collapse in Western Australia's far north does not make sense without including stolen wages and stolen pension moneys as crucial factors in that collapse.

In the Kimberley, the economic contribution made by Aboriginal people to the pastoral industry was just one of three types of subsidy that sustained the economy. It was the end-in the mid to late 1960s - to this tripartite subsidy that had such a profound impact on that economy, and shattering social consequences for the Aboriginal people who comprised the majority of the pastoral workforce in the Kimberley. Another type of subsidy was that pastoral lease rents were kept extremely low by the State Government until the late 1960s, when rent levels increased dramatically. In 1969 pastoral lease rents paid by Kimberley station owners were trebled, and increased again by between two and four times in 1979. A further type of subsidy that supported the 
Kimberley regional economy were Commonwealth pension cheques intended for Aboriginal people. It seemed that after government policy changes in 1965 and 1966 it became increasingly difficult for station owners to misappropriate old-age pension payments for Aboriginal people as many of them had done in previous years. Elderly station residents who had represented a source of Commonwealth Government money for the stations were no longer an economic advantage to station owners. The withdrawal of this unacknowledged yet substantial stream of station income was, I argue, an important factor in the mass evictions that coincided with the introduction of equal wages for Aboriginal workers. An increase in Aboriginal wages was only part of the history of the era of devastation for Kimberley Aboriginal people.

The very low labour cost of the Aboriginal pastoral workforce-imposed through a racially discriminatory legislative and administrative regime - was one type of subsidy that enabled station owners to remain economically viable. Unpaid or underpaid Aboriginal workers underpinned station profitability. Thalia Anthony has reached similar conclusions in relation to the operation of the cattle industry in the Northern Territory (Anthony 2007:5-6). Anthony has written extensively about the feudal nature of the Northern Territory's pastoral industry (Anthony 2004, 2007). In the Kimberley, prior to 1950, most Aboriginal station workers were paid no wages at all, and were given food, clothing and tobacco rations in return for their labour (ALSWA 2006b:7). Various commentators have for a long time identified the feudal basis of the relationship between Aboriginal workers and station owners in the northern pastoral industry, and it was also referred to as a system of slavery. In 1910 the Australian Workers' Union (AWU) condemned it as 'a demoralising system of employing native labour in Western Australia', and sent their 'emphatic' protests to the newly elected Labor Prime Minister, Andrew Fisher. ${ }^{2}$ AWU delegates in 1910 argued that the condition imposed on the natives in Western Australia is a blot on our boasted civilisation - worse than on the cotton fields of America before the Civil War', and they sought publicity for the abuses as a way of promoting reform. They condemned the WA Government because 'a system of the most abject slavery was allowed to exist through official indisposition' (The Worker, 2 February 1910).

The AWU delegates were right. In 1925 Chief Protector A. O. Neville wrote that many Aboriginal workers in Western Australia existed 'under a system of semi-slavery'. ${ }^{3}$ This did not trouble the Chief Protector at all, and through to the equal wages decision in 1967 the State Government administered a

2 General Secretary of AWU to Prime Minister Fisher, 14 February 1910, item A63, A1910/4980, 'Employment of native labour in WA', National Archives of Australia (NAA), Canberra.

3 A. O. Neville to Hon. Minister for the North West, 3 October 1925, in 'Payment of wages to natives', item 1933/0451, State Records Office of Western Australia (SROWA), Consignment (Cons.) 993. 
system of low-cost bonded Aboriginal labour throughout the pastoral regions of the State, with penalties for Aboriginal workers who sought to leave or to challenge the boss. Even after 1963, when most of the punitive aspects of socalled 'protective' legislation had been repealed, the records show that the Native Welfare Department in the Kimberley acted like an employment agency for station managers, sending Aboriginal workers when asked.

John Watson, former Chairman of the Kimberley Land Council, described it this way:

From the early days Aboriginal people were forced to work on the stations. The police issued the station managers with permits to work the Aboriginal people and to take charge of their welfare. That happened right across the Kimberley. All the stations came to depend upon cheap Aboriginal labour. The Aboriginal people knew they were being exploited but they didn't have any choice. Then, during the 'fifties and 'sixties Aboriginal stockmen started pushing for better wages. They didn't realize the drastic effect it would have on their lives.

When the equal wages decision was handed down by the Courts twentyodd years ago, the Aboriginal people were forced off the stations. Hundreds of people were forced to leave the stations they'd grown up on, and to live under appalling conditions in town reserves. Those station managers just came out and said, 'We can't afford to pay you the basic wage, and we can't afford to keep feeding you. The Welfare mob have a lot of money for you to live on in the town. So pack up your camp and start walking'. (Marshall 1998:208)

For the former Kimberley stockmen who published their recollections, the introduction of equal wages was remembered as devastating. Senior Walmajarri man Eric Lawford recalled that the Emanuel family, who owned Christmas Creek Station, decided they would pay only a few stockmen and that everyone else had to leave the station. Out of a community of 300 or 400 people, Lawford estimated, most were forced off the station into the temporary camp at Fitzroy Crossing. 'That's how they split this community up!' Lawford said (Marshall 1998:23-6). John Watson, who by his own description was 'born into the pastoral industry' and spent much of his adult life working as a stockman, recalled 'drinking rights came in at the same time as the equal wages' (Marshall 1998:209). An increase in alcohol consumption followed when the prohibition on Kimberley Aboriginal people buying or consuming alcohol was removed. Between 1970 and 1971, they, along with Aboriginal people in the Goldfields, were among the last groups of Aboriginal people to have been targeted by 
these prohibition clauses under the Native Welfare Act. ${ }^{4}$ Increased drinking by people in the reserve camps, unemployment and widespread homelessness all happened at roughly the same time for Kimberley Aboriginal people. These changes conflated as one catastrophe.

Across the Kimberley, Aboriginal people were evicted from the stations and congregated in squalid refugee camps at Fitzroy Crossing, Halls Creek, Broome and Derby. When managers from Christmas Creek Station south-west of Fitzroy Crossing removed the Aboriginal workforce and their families from the station and left them on the banks of the Fitzroy River in January 1969, that started what was soon to become a refugee population of more than 200 people. They had very little food, no money except some women's and children's bankbook balances averaging $\$ 3$, and only a few pit latrines for the entire camp. Many families did not even have tents for shelter and trachoma was endemic amongst the children. More Aboriginal workers and their families were evicted from or walked off stations in the Fitzroy Valley and congregated at the camp, which by 1971 had increased to between 600 and 700 people (Eggington and Skyring 2006:xxi-xx). And that was just in Fitzroy Crossing. The State Government's officers in the Native Welfare Department wrote reports on the 'displaced persons' in equally impoverished and overcrowded makeshift camps at Derby, Broome and Halls Creek. At Halls Creek there were 600 people camped there over the wet season and even though some of the men worked out of town as contractors, there was an acute shortage of housing in town for their families. ${ }^{5}$

The equal wages decision was portrayed in Bunbury's book It's Not the Money It's the Land as one imposed from afar with no thought for the social consequences or communication with the people directly affected - the station owners and the Aboriginal station residents. While some stations retained their employees on the lesser 'slow worker' rate allowed in the new award, the impact on other stations was a drastic decline in the station population as only the younger skilled workers and their immediate families were allowed to stay. Bunbury wrote with sympathy for both station owners and Aboriginal people, and referred to the 'long standing relationship - not an equal one but a relationship nonetheless' that was broken with the introduction of award wages. He said that in talking with people about the event, it was remembered with 'mutual regret rather than blame' (Bunbury 2002:12).

The Kimberley stockmen in Raparapa did not express any nostalgia for their former bosses in the same way that the station owners in Bill Bunbury's account fondly recalled their Aboriginal employees. Rather, these former stockmen

4 Minister for Native Welfare, E. M. Lewis, 18 September 1970, in 'Native Citizenship Rights General Correspondence', item 1964/0249, SROWA, Accession (Acc.) 1733.

5 Report from K. Johnson, 27 June 1969, in 'Pastoral Industry Award 1968 - Welfare of Unemployed natives ex. Pastoral stations', item 1969/0116, SROWA, Acc. 1733. 
recalled with pride their skill at all kinds of station work, from fencing and building windmills to mustering. They also remembered how they trained the white men sent to manage them. Kimberley native title holders told much the same story in the Karajarri, Rubibi and Neowarra native title trials in the Federal Court. As a young stockman, senior Yawuru man Paddy Roe worked on Roebuck Plains Station, which is in Yawuru country. He remembered that working on the station was a 'hard life' but also a 'good life' because they had few worries. Steve Possum, a senior Karajarri man, said that he really liked stock work and had good memories of life on Thangoo Station and on Frazier Downs, a station in Karajarri country. Even though he considered himself to be the 'right-hand man' to the station manager at Frazier Downs, Steve Possum used the word 'slave' to describe how they worked for no money (ALSWA 2006b:17-18). Women did station work as well. As a young woman, senior Karajarri woman Edna Hopiga helped to build fences at Frazier Downs, where her brother was the boss for that job. Gordon Smith worked as a stockman in Ngarinyin country, which was his traditional country. In response to a question during the Neowarra native title trial about the kind of pay he received, Smith replied: 'Nothing. I was just working for my pride, that's all' (ALSWA 2006b:18).

Until the equal wages decision, Aboriginal pastoral workers were specifically excluded from being paid the wage rates stipulated in the Federal Pastoral Industry Award, which was very similar to, though not the same award as, the Cattle Station Industry (Northern Territory) Award. In 1968 the Federal Pastoral Award for a station hand working 44 hours a week was between $\$ 38.90$ and $\$ 41$ per week, less $\$ 9.41$ for food and accommodation (West Australian, 27 February 1969). Most Aboriginal men working on stations in the Kimberley at that time were paid between $\$ 6$ and $\$ 20$ per week, with stockmen receiving the highest wages and 'yardmen' and older workers on the lowest rates. These payments represented between 19 per cent and 63 per cent of the award, minus the cost of food and accommodation. Many of these older workers in the late 1960s had been skilled and valuable station employees in their younger days when they were paid no wages at all. Aboriginal women who worked on the stations in 1968 - many of them as domestic servants in the homestead-were paid between \$3 and \$10 per week (ALSWA 2006b:22-3). Some stockmen referred to in the records as 'half caste' received the same wages as white stockmen, but through to the late 1960s most Aboriginal men, women and teenagers working on stations in the Kimberley did so for little money. In September 1967, the Commonwealth Conciliation and Arbitration Commission decided to remove the racially discriminatory clause from the federal award (the decision in relation to the NT award had been made in 1966), and equal wages for Aboriginal pastoral workers were phased in from December 1968 during the wet season in the Kimberley (Chesterman 2001:207-12). 
In 1944 when the AWU first took up the case to amend the Federal Pastoral Award and remove the racially discriminatory clauses, their respondents were the graziers' associations of New South Wales and Western Australia, and others. ${ }^{6}$ The Kimberley station owners who talked with Bill Bunbury gave the impression that they were innocent bystanders to the decision to pay equal wages to Aboriginal pastoral workers (Bunbury 2002). But this is not correct. Station owners fought collectively against the introduction of decent wages for Aboriginal workers over decades, starting with the first challenge in the Conciliation and Arbitration Commission in 1944. In 1950 station owners opposed the first attempts by the WA Government to introduce minimum wages for Aboriginal workers in the north-west. The station owners who criticised the introduction of the award in 1968-69 were the same people who had earlier opposed attempts to introduce a wage system for Aboriginal workers. In 1971, West Kimberley Shire President Rowell was reported as saying that the introduction of award wages had done 'much harm' and that 'most Aborigines had not been ready to handle the situation' (West Australian, 3 June 1971). In 1950 Rowell was one of the well-known west Kimberley station ownersincluding the Blythes, J. Forrest, the Duracks and the Roses - who attended a meeting in Perth where he and fellow pastoralists argued against paying their Aboriginal employees anything. At the 1950 meeting they reluctantly agreed with the Commissioner of Native Affairs to pay Aboriginal stockmen $£ 1$ per month, and 'yardmen' and women employees 10 shillings (10 s) per month. ${ }^{7}$ These minimum rates for Aboriginal workers were slightly below what the State Government had proposed (between $£ 1$ and $£ 3$ per month for stockmen) and way below award rates for white workers. Nevertheless, station owners complained that 'misinformed' public opinion was forcing them to pay wages. They also wrote this:

The consensus of opinion of the meeting was that the present system whereby working natives, their dependents and pensioners, were provided with all the necessities of life, virtually from the cradle to the grave, was the one best suited to the present stage of development of the natives in the area, and one moreover calculated to avoid the evils inevitably associated with the circulation of money, among the native people not generally educated to its value. ${ }^{8}$

That money was a source of harm for Aboriginal people is a theme that is repeated throughout the history of labour in Western Australia. It was regularly stated by employers and by government officials as an argument for restricting

6 Judgment, 1 September 1944, The Graziers' Association of NSW and Ors $v$ the Australian Workers Union,

in 'Federal Pastoral Award-Employment of Natives', item 1946/1010, SROWA, Acc. 1733.

7 Circular, 13 March 1950, from Pastoralists' Association of Western Australia, in ibid.

8 Ibid. 
cash payments to Aboriginal workers (ALSWA 2006b:7-8). Yet this invented inability of Aboriginal people to fully participate in the mainstream economy belied the very real contribution they made to that economy. The low-wage system for Aboriginal pastoral workers provided a massive subsidy for station owners. The top award rate for an adult male station worker in 1951 was £10 8s with 'keep', which was food and accommodation provided by the employer.' Compared with these wages, most skilled Aboriginal stockmen were paid about 3 per cent, or less than one-twentieth, of the award. In 1951 station owners in the Kimberley were saving more than $£ 520$ a year in labour costs on every skilled Aboriginal male worker, except for the few head stockmen who were paid close to award wages. The net value of pastoral production for the year 1949-50 was £26 million, and Native Affairs Commissioner, Stanley Middleton, argued that Aboriginal pastoral workers had made a substantial contribution towards this total. ${ }^{10}$ Even if the station owners were providing food rations to a number of elderly dependants of each adult male worker - which was the main argument they used to justify low or non-existent wages - the value of these rations per week would have come nowhere near the difference between $5 \mathrm{~s}$ and $£ 10$ 8s. The difference in these amounts was $£ 10$ 3s, and equivalent to more than three times the weekly old-age pension in 1950 (Department of Social Security Research and Statistics Branch 2006:115).

The wage differential was not quite as extreme when equal wages were phased in for Aboriginal workers in 1968-69, and then most Aboriginal men were earning between 19 per cent and 63 per cent of the award rate. Even with this slightly lesser difference, it was a saving of at least \$12 per adult male worker per week. This represented an annual subsidy for station owners of at least \$624 for each Aboriginal stockman. With a total of 931 Aboriginal men employed on Kimberley stations in 1968, the annual labour cost saving for station owners in the region was close to $\$ 581000$, and this is a conservative estimate based on wage rates for Aboriginal male workers being 63 per cent of the award wage. This did not include the cost savings on the 628 Aboriginal women who were recorded as being employed (Altman and Nieuwenhuysen 1979:66, for numbers of Aboriginal employees). Non-payment and underpayment of wages to Aboriginal workers represented, over the decades to 1969, an enormous labour cost subsidy for station owners. As a Native Affairs patrol officer commented of two Kimberley stations in 1949:

Both places are enjoying extremely cheap labour-both know it, but are wondering how much longer these dreamlike conditions are to continue. That they are all alive to impending changes is very evident-

9 Circular, 6 November 1951, from Pastoralists' Association of Western Australia, in ibid.

10 S. G. Middelton, 25 August 1952, in 'Native Policy in Western Australia', item 1945/0803, SROWA, Acc. 1733. 
partly in their demeanour and partly in their desire to talk about the natives - a sure sign of nervousness - and to put forward their own ideas...Arguments against the payment of wages to native workers are rarely heard now, but the question has progressed to the stage of how much they should be paid and the mechanics of paying. This is a definite advance in public opinion in the short period of from 4 to 5 months ago. ${ }^{11}$

Although no Kimberley Aboriginal pastoral workers were involved in the AWU's case in the Conciliation and Arbitration Commission, there had been industrial action in the Kimberley prior to 1967. In 1951 the Aboriginal workforce at Thangoo, south of Broome, walked off the station because management refused to pay them $£ 4$ per week plus rations (still less than half of the award rate). In the mid-1960s at Mount Hart Station in the central Kimberley, Aboriginal workers staged several walk-offs in protest against ill treatment by the manager, Jack Webber, and because he refused to pay their wages. In one instance in 1966, Webber followed a group of men with a rifle and 'persuaded' them to return with him in the truck. Once back at the station, Webber placed a horse's bridle on one of the Aboriginal men as punishment for leaving the station. Aboriginal workers and their families did not return to Mount Hart until the manager was replaced in 1967 (ALSWA 2006b:19-20). The pressure for decent wages intensified in the 1960s - much of that pressure coming from Aboriginal workers themselves. As John Watson said, they knew they were being exploited.

Another form of subsidy for Kimberley station owners that was also under threat by the 1960s was the extremely cheap pastoral lease rents throughout the region. In 1948 the reappraisal of Kimberley pastoral lease rents identified them as substantially undervalued, based on estimates of stock carrying capacity. The WA Surveyor General concluded that rents should be increased fourfold but this was not possible under the Land Act, and the Surveyor General recommended legislative changes to enable the increased rents to be imposed. ${ }^{12}$ Government reports from the 1950s onwards were generally critical of the standard of land management on Kimberley stations. The irreversible environmental damage caused by uncontrolled grazing, no fences and inadequate station improvements, and the corresponding steady decline in herd quality, meant that the vast pastoral areas of the north were not as economically productive as they should have been. ${ }^{13}$ The old-style cattlemen - and these included the financially marginal resident owners and the more numerous absentee landlords - were regarded by government policy makers as an impediment to development of the north. The State Government had invested in better roads and transport

11 Patrol report, West Kimberley, 2-9 September 1949, in 'Wages. Scale for natives in the Kimberley District. Implementation of', item 1949/0034, Cons. 993, SROWA.

12 W. Fyfe, Surveyor General, 17 June 1952, in 'Reappraisement of pastoral lease Kimberley Division 1948', item 1950/1987, Cons 6231, SROWA.

13 Reports by G. A. Buchanan, February 1951, and W. W. Henwood, Inspector, November 1950, in ibid. 
infrastructure in the Kimberley in the decades after World War II, but there had been little corresponding capital investment from the pastoral leaseholders themselves. Pastoral Inspector Bill Henwood was particularly critical of what he called 'absentee owners', mostly based in Perth, who refused to invest in improvements and often stymied resident managers' attempts to run the stations to acceptable standards. ${ }^{14}$

In a report for the Commonwealth Bureau of Agricultural Economics in 1952, the author, J. H. Kelly, found that there was only one station in the Kimberley that he considered to have adequate station improvements. His central argumentsubstantiated by statistical research - was that the underdevelopment of the beef industry in the north was because of poor pastoral land management and inadequate herd control. Kelly also condemned the majority of station owners in the Northern Territory and the Kimberley for the deplorable conditions under which their Aboriginal employees lived and worked. He identified the neglect of Aboriginal people as a central problem in the lack of development of the beef industry in northern Australia (Australian Bureau of Agricultural Economics 1952).

By the late 1960s the WA Government was becoming less willing to tolerate substandard land and herd management by station owners in the Kimberley. In 1969 the WA Pastoral Appraisement Board considered that extremely low pastoral lease rents promoted inefficient land use, and should be reviewed 'in the light of modern day practice and economics'. The Kimberley pastoral leases returned about $\$ 40000$ in terms of rentals to the State Government, and this represented only about 1 per cent of the actual gross returns to pastoral stations of livestock sold. The Pastoral Appraisement Board thought it was fair that rents should increase so that the total rent was 2.5 per cent of gross returns, and the board recommended this to the minister (Pastoral Appraisement Board 1969). The Pastoral Appraisement Board's proposal represented an increase of about 600 per cent in annual pastoral lease rents, but the board suggested it was 'more prudent' to limit this increase to 400 per cent. In the end, the State Government decided to limit the pastoral lease rent increase for Kimberley stations to 300 per cent, effective 1 July 1969. Pastoral lease rents were again increased in the Kimberley division in 1979 by between two and four times the 1969 annual rental, with some stations paying substantially larger increases than others. The Pastoralists' and Graziers' Association argued with the State Government against these increases (Pastoral Appraisement Board 1979). By 1969 the days of negligible land costs for Kimberley station owners were over.

The third form of subsidy for the Kimberley pastoral industry started in 1960 with the removal of racially discriminatory clauses in Commonwealth legislation governing the payment of old-age pensions and maternity allowances.

14 W. W. Henwood, Inspector, November 1950, in ibid. 
The amendments meant that for the first time many Aboriginal people living on pastoral stations across Western Australia became eligible to receive these Commonwealth benefits. A Native Welfare officer in Derby described it as 'a flood of money' into the Kimberley economy (Jebb 2002:260). On the eve of the legislative changes, a memo was distributed to all Native Welfare Department field officers detailing the administrative arrangements for distribution of Commonwealth benefits. It listed the amounts of 'pocket money' that would be paid in cash to each pension recipient, with the remainder held by the various mission authorities and station owners for 'maintenance' of the pensioners and improvements in their accommodation. Missions and station owners or managers were appointed warrantees so they could receive the cheques, and those pensioners resident on pastoral stations would each receive 10 s in cash, which was 10 per cent of the weekly pension payment of $£ 5$ in $1960{ }^{15}$

By the mid-1960s both State and Commonwealth Government officials at the most senior levels knew that abuses were widespread, and that many stations kept most of the Commonwealth benefits intended for Aboriginal people. A senior Native Welfare officer commented of the station owners that '[t]hey are all making a quid out of the pensioners' ${ }^{16}$ The Department of Social Services appointed Special Magistrate Davies to investigate the allegations of misappropriation, and he conducted reviews of stations across the Kimberley in 1965 and 1966. Decimal currency was introduced in Australia in February 1966, so Magistrate Davies' investigation included results in pounds, shillings and pence and in decimal currency figures. He found that several stations were charging hugely inflated prices for food rations provided to pensioners, and on one station this charge was more than the value of the pension itself. Commonwealth cheques were going to station owners in Perth and Melbourne, with no accounting for the amounts supposedly spent on food and clothing for the pensioners. The owner of one Kimberley station, who actually lived in Melbourne, was charging hugely inflated prices for food rations provided to the nine pensioners on the station, and Magistrate Davies doubted that these pensioners received the full food ration anyway. At another station there were no built dwellings to house the pensioners and the owner charged each pensioner $£ 60$ s $5 \mathrm{~d}$ for substandard food rations, which was more than the full value of their $£ 6$ pension payment. Magistrate Davies considered that one prominent station-owning family acted like 'a law unto themselves' and set the example for other Kimberley stations to use Aboriginal pensioners' money however they liked. They charged pensioners $£ 4$ 15s per week for food, and the accommodation the station owners provided

15 Commissioner of Native Welfare, Circular memo, 24 December 1959, in ‘Old Age and Invalid pensions for natives - general file', item 1939/1104, Cons. 993, SROWA. (A copy of this is in Supplementary information to submissions from ALSWA November 2006 at Submission 30C: <http://www.aph.gov.au/senate/committee/ legcon_ctte/completed_inquiries/2004-07/stolen_wages/submissions/sub30C.pdf $>$ )

16 K. Johnson, 8 August 1966, in 'Social Services. Pensions-general', item NDG 33/3/1a, Cons. 3412, SROWA. 
was described by Davies as 'disgustingly filthy'. The station owners claimed that a shed had cost $£ 700$ to build, and that same amount had been transferred from the pensioners' account to the station account. The use of pensioners' money to build sheds to house them was a policy openly encouraged by both the State and the Federal Governments, but pensioners did not share in the ownership of these station improvements paid for with their money (ALSWA 2007:1-14).

The amounts of money paid to the stations as Commonwealth benefits intended for Aboriginal people were substantial. One Kimberley station collected a total of \$30 268 in Commonwealth benefits between 1960 and 1966, and the pensioners on this station were not given any cash pocket money but were given biscuits and lollies instead, freighted from Perth. Another station collected £9 900 in pension cheques between January 1962 and April 1964, and never paid pensioners anything. A manager on one east Kimberley station withdrew all the money from the pensioners' account and took it with her when she cleared out. No-one was ever prosecuted for these identified instances of misappropriation and theft, and despite complaints by the Department of Social Services it seemed that their only practical response to the perpetration of such abuses was to cancel pension payments entirely on some stations (ALSWA 2007:1-14).

In mid-1965 the Director of Social Services in Western Australia wrote to his boss, the Director General in Canberra:

It seems that some warrantees regard the pension as a form of station subsidy and consider that they are entitled to restrict the value of the benefits flowing to the pensioners for various reasons. One being that wages paid to native station workers will not show adversely by comparison.

The effect is that instead of Commonwealth pension moneys benefiting the pensioners only, they are undeservedly and unnecessarily benefiting the station to the extent to which value is withheld from the pensioner. ${ }^{17}$

The fact that many skilled Aboriginal workers were being paid the same as, or sometimes less than, the value of the old-age pension-a subsistence welfare payment - was a further pressure for award wages. Station owners resisted that pressure in a number of ways, one of which was to keep most of the Commonwealth pension cheques for themselves so the disparity would not be so obvious. More research needs to be done on the rise and demise of the Aboriginal pension money bonanza for Kimberley station owners, but it appeared from the departmental response that the more flagrant abuses by warrantees declined after Davies' investigations in 1965 and 1966.

17 Director Humphreys, 2 July 1965, in ibid. 
So there were three types of substantial economic subsidies pastoral leaseholders received: from the Aboriginal workforce in the form of unpaid or underpaid labour; from the State Government as cheap rent way out of proportion to the value of their leases; and from elderly Aboriginal people in the form of Commonwealth social services benefits. Cheap Aboriginal labour, cheap rent and, from 1960, Commonwealth social services benefits intended for Aboriginal people sustained the pastoral economy in the Kimberley. In the space of a few years from the mid-1960s into the early 1970s, this tripartite subsidy was withdrawn under pressure from Aboriginal people themselves and from governments tired of supporting an inefficient and embarrassingly feudal industry. The introduction of award wages and of realistic lease rentals had both been a long time coming and pastoral leaseholders were well aware of these developments, since they had actively resisted both reforms since the 1940s and 1950s. A few station owners responded to criticism of their poor land management and inadequate station improvements and changed their practices, but most did not. With a few exceptions, most station owners ignored increasing demands over decades for them to improve housing and living conditions for their Aboriginal employees in lieu of direct wage increases. With the social security cheque bonanza, several station owners were genuine in passing on the value of those payments to their elderly former employees, but the investigations in 1965 and 1966 showed that too many station owners abused the system for their own benefit. The end of opportunity for such abuses was also something these station owners must have foreseen.

The Christmas Creek managers who kicked the station workers and their families off the station and left them on the banks of the Fitzroy River in January 1969 were not just responding to the equal wages decision. This was not the result of actions by heartless city folk in a cold, distant courtroom, but the outcome of a combination of changes that had been a long time in the making and with which Kimberley people were very familiar. When the tripartite subsidy of low labour costs, cheap lease rents and Commonwealth benefits intended for Aboriginal people was removed from the equation, the local economy declined dramatically. The people who suffered the most in this economic collapse were the Aboriginal people whose labour had built the pastoral industry and whose pension cheques had boosted station accounts in the 1960s. Many of the people in the reserve camps across the Kimberley had in their own lifetime gone from no wage to low wage to unemployment benefits.

The chronic poverty of Aboriginal communities in the Kimberley that effectively began as refugee camps in the late 1960s and early 1970s did not start with the introduction of equal wages and the sudden move to welfare dependency. Aboriginal workers and their families had always lived in poverty on the stations. Government reports had for decades identified this poverty as an impediment 
to regional development, and Aboriginal people themselves protested against their enforced low wages and poor living conditions. But the difference in 1969 in places like Fitzroy Crossing and Halls Creek was that Aboriginal workers and their families were homeless and unemployed as well as poor.

The history of the northern pastoral economy and the central role that Aboriginal people played in the development of that economy, both as workers and as recipients of Commonwealth pension benefits, deserves more research. The introduction of equal wages was only part of the history of the station exodus that had such traumatic outcomes for Aboriginal people in the Kimberley. When the tripartite subsidy that upheld the northern pastoral economy was removed, there was little to sustain it and the regional economy collapsed. Jon Altman, in an introduction to his co-edited book (Altman, 2010), addresses the dominant development paradigm that has become the standard, and completely ineffective, response to the poverty and dysfunction of much of remote Aboriginal Australia. In the light of Altman's analysis of the contemporary situation and his conclusion that policy responses so far have been a destructive failure, the question worth asking is whether the northern regional economy was ever a normal modern economy in the first place. It had long been identified as feudal or based on slavery. In the postwar 'golden era' of the pastoral industry in the Kimberley, a closer interrogation of its history showed that it functioned only with subsidies that were huge and largely unacknowledged and, in later years, illicit. Without acknowledging the enormity of the value of Aboriginal people's underpaid or unpaid wages and their stolen pension cheques, contemporary policy responses miss a central point. Aboriginal poverty and the economic dysfunction of many remote Aboriginal communities did not start with welfare dependency in 1969; they were created through dispossession of Aboriginal land and of the value of Aboriginal labour across generations (Eggington and Skyring 2006: xxi). These are the origins of intergenerational poverty. And while government policy responses to remote poverty continue to fail, the Aboriginal people from whom the most has been taken to sustain the northern economy - their land, the value of their labour and for a number of years their pension cheques - continue to be the ones who lose the most.

\section{References}

Aboriginal Legal Service of Western Australia Incorporated (ALSWA) 2006a. Submission from ALSWA, July 2006, to the Senate Legal and Constitutional Affairs Committee Inquiry into Stolen Wages. Submission no. 30, <http://www.aph.gov.au/senate/committee/legcon_ctte/completed_ inquiries/2004-07/stolen_wages/submissions/sub30.pdf> 
Aboriginal Legal Service of Western Australia Incorporated (ALSWA) 2006b. Further submission from ALSWA, October 2006, to the Senate Legal and Constitutional Affairs Committee Inquiry into Stolen Wages. Submission no. 30B, <http://www.aph.gov.au/senate/committee/legcon_ctte/completed_ inquiries/2004-07/stolen_wages/submissions/sub30b.pdf>

Aboriginal Legal Service of Western Australia Incorporated (ALSWA) 2007. Correspondence received from the Aboriginal Legal Service of Western Australia dated 26 March 2007, re Senate Legal and Constitutional Affairs Committee, Inquiry into Stolen Wages, including Attachment 1, Parts 1 and 2. Additional information received, <http://www.aph.gov.au/senate/ committee/legcon_ctte/completed_inquiries/2004-07/stolen_wages/ submissions/sublist.htm>

Altman, J. 2010. What future for remote Indigenous Australia? Economic hybridity and the neoliberal turn. In J. Altman and M. Hinkson (eds), Culture Crisis: Aboriginal politics in Aboriginal Australia. Sydney: UNSW Press.

Altman, J. and Nieuwenhuysen, J. 1979. The Economic Status of Australian Aborigines. Cambridge: Cambridge University Press.

Anthony, T. 2004. Labour relations on northern cattle stations: feudal exploitation and accommodation. Drawing Board: An Australian Review of Public Affairs 4 (3): 118-36.

Anthony, T. 2006. Equal pay: an anniversary shrouded in myths. Australian Policy Online, 22 August 2006. <http://www.apo.org.au/webboard/results. chtml?filename_num $=95297>$

Anthony, T. 2007. Crime and transgression on northern cattle stations. In I. MacFarlane and M. Hannah (eds), Transgressions: Critical Australian Indigenous histories. Canberra: ANU E Press. <http://epress.anu.edu.au/ transgressions_citation.html > ; <http://epress.anu.edu.au/aborig_history/ transgressions/pdf/ch03.pdf>

Australian Bureau of Agricultural Economics 1952. Report on the Beef Cattle Industry in Northern Australia, by J. H. Kelly. Canberra: Australian Bureau of Agricultural Economics.

Bunbury, B. 2002. It's Not the Money It's the Land: Aboriginal stockmen and the equal wages case - talking history with Bill Bunbury. North Fremantle, WA: Fremantle Arts Centre Press.

Chesterman, J. 2001. Defending Australia's reputation: how Indigenous Australians won civil rights. Part two. Australian Historical Studies (117) (October): 201-21. 
Department of Social Security Research and Statistics Branch 2006 [1983]. Developments in social security: a compendium of legislative changes since 1908. Department of Social Security Research Paper No. 20, Commonwealth of Australia, Canberra.

Eggington, D. and Skyring, F. 2006. Preface. In S. R. Silburn, S. R., Zubrick, J. A. De Maio, C. Shepherd, J. A. Griffin, F. G. Mitrou, R. B. Dalby, C. Hayward and G. Pearson (eds), The Western Australian Aboriginal Child Health Survey: Strengthening the capacity of Aboriginal children, families and communities. Perth: Curtin University of Technology and Telethon Institute for Child Health Research.

Jebb, M. A. 2002. Blood, Sweat and Welfare: A history of white bosses and Aboriginal pastoral workers. Perth: University of Western Australia Press.

Marshall, P. (ed.) 1989. Raparapa Kularr Martuwarra: All right, now we go 'side the river, along that sundown way-stories from Fitzroy River drovers. Broome, WA: Magabala Books.

National Archives of Australia (NAA) Item A63, A1910/4980, 'Employment of native labour in WA', NAA, Canberra.

Pastoral Appraisement Board 1969. Report of Pastoral Appraisement Board on Reappraisement of Pastoral Leases, Kimberley Division, 1969. Perth: Department of Lands and Surveys.

Pastoral Appraisement Board 1979. Report of the Pastoral Appraisement Board on the Reappraisement of Pastoral Leases, Kimberley Division, 1979. Perth: Department of Lands and Surveys.

State Records Office of Western Australia (SROWA), Item 1933/ 0451, 'Payment of wages to natives', Cons 993.

SROWA Item 1939/1 104, 'Old Age and Invalid pensions for natives - general file', Native Welfare Department archival file. A copy of this is in Supplementary information to submissions from ALSWA November 2006, on the Senate Committee website at <http://www.aph.gov.au/senate/committee/legcon_ ctte/completed_inquiries/2004-07/stolen_wages/submissions/sub30C.pdf>

SROWA, Item 1945/0803, 'Native Policy in Western Australia', Acc 1733.

SROWA 1946/1010, 'Federal Pastoral Award - Employment of Natives', Acc. 1733.

SROWA Item 1949/0034, 'Wages. Scale for natives in the Kimberley District. Implementation of', Cons. 993. 
SROWA, Item 1950/1987, 'Reappraisement of pastoral lease Kimberley Division 1948', Cons 6231.

SROWA, Item 1964/ 0249, 'Native Citizenship Rights General Correspondence', Acc. 1733.

SROWA, Item NDG 33/3/1a, 'Social Services. Pensions - general', Cons. 3412.

SROWA, 1969/0116, 'Pastoral Industry Award 1968 - Welfare of Unemployed natives ex. Pastoral stations', Acc. 1733.

Yu, P., 1994, Aboriginal Peoples, Federalism and Self-Determination. In Social Alternatives, Vol. 13, No. 1, April 1994, pp. 19-21. 